\title{
KONTRIBUSI PRINSIP-PRINSIP PENGAJARAN DALAM PRAKTIK INSTRUMEN MUSIK GESEK
}

\author{
Oleh: Agustianto \\ Jurusan Pendidikan Seni Musik FBS-UNY \\ Email: agustyviolin@gmail.com
}

\begin{abstract}
Abstrak
Kajian ini bertujuan untuk mendiskripsikan mengenai beberapa prinsip-prinsip yang dapat diterapkan pada praktik pengajaran instrumen musik gesek di sekolah. Pembahasan ditekankan pada pelaksanaan pembelajaran dengan didasarkan pada 7 prinsip pengajaran, yang meliputi: prinsip aktivitas, prinsip motivasi, prinsip individualitas,prinsip lingkungan, prinsip kebebasan, prinsip peragaan, prinsip kerjasama dan persaingan. Di dalam pelaksanaan pembelajaran, setiap prinsip pengajaran memberikan kontribusi yang diharapkan dapat meningkatkan kualitas permainan musik gesek (violin, violia,cello, contra bass) baik dari segi penguasaan materi, kedisiplinan dalam pelaksanaan pembelajaran maupun pemberian motivasi bagi setiap peserta didik serta bagaimana dapat menciptakan suatu kerjasama dan persaingan yang sehat. Peran guru praktik dengan peserta didik dalam hal ini diharapkan ada keseimbangan, sehingga peserta didik bisa mengakomodasi semua instruksi yang diberikan oleh guru sebagai suatu masukan ataupun input yang tidak terlalu dipaksakan kepada peserta didik.
\end{abstract}

Kata kunci: Prinsip pengajaran, Praktik instrumen.

\section{THE CONTRIBUTIONS OF TEACHING PRICIPLES IN STRINGED MUSICAL INSTRUMENTS TEACHING PRACTICE}

\begin{abstract}
This study aimed to describe about some principles that can be applied to teaching practices in stringed musical instrument at schools. The discussion focused on the implementation of learning with teaching based on seven principles, which include: principles of activity, motivation principle, the principle of individuality, environmental principles, the principle of freedom, the principle of demonstration, the principle of cooperation and competition. In the implementation of learning, every principle of teaching contribution is expected to improve the quality of strings instrument such as violin, violia, cello, contra bass, both in terms of mastery of the material, discipline in the implementation of learning and motivation for each learner as well as how to create a cooperation and fair competition. The role of teachers in this practice class with learners in this regard is expected to balance, so that learners can accommodate all the instructions given by the teacher as an input that are not too hard for the learners.
\end{abstract}

Keywords: Teaching Principles, Instrument Practices 


\section{A. PENDAhuluan}

Dalam kegiatan berkesenian terutama pada bidang seni musik, baik itu musik diatonis maupun musik pentatonis (tradisi) tidak akan pernah lepas dari unsur-unsur yang berkaitan dengan masalah yang disebut dengan musikalitas. Musikalitas adalah hal yang sangat penting untuk dimiliki bagi seseorang yang mendalami bidang seni musik, karena musikalitas merupakan faktor pendukung untuk keberhasilan seseorang untuk menguasai permainan musik, orang yang tidak mempunyai bakat dalam bidang musik tentu akan banyak mengalami kesulitan dalam belajar memainkan instrumen musik dengan baik. Namun hal tersebut bukan berarti seseorang yang tidak punya bakat atau dalam hal ini disebut dengan daya musikal rendah tidak bisa belajar memainkan musik dengan baik. Sebenarnya pada diri setiap orang ataupun setiap individu mempunyai bakat musikal yang dibawa sejak manusia dilahirkan, hanya tingkat daya musikal yang dimiliki berbeda-beda pada diri setiap orang atau individu, ada yang mempunyai daya musikal yang tinggi dan ada pula yang mempunyai daya musikal tetapi pada tingkat yang rendah. Untuk meningkatkan ataupun memperkuat daya musikal seseorang, pada bidang seni musik ada satu bentuk latihan untuk meningkatkan daya musikalitas yang disebut dengan latihan solfegio.

Solfegio adalah satu bentuk latihan musikal dengan menyajikan unsur-unsur penting dalam musik yaitu ritmis, nada, melodi, harmoni. Keempat unsur tersebut saling berkaitan dan saling mendukung antara satu dengan yang lain. Indikator keberhasilan serta kemajuan individu dalam latihan solfegio adalah seseorang bisa mendengarkan maupun menirukan dengan tepat sesuai dengan suara yang diperdengarkan, hal tersebut dapat diketahui dari hasil yang dipraktikkan, baik itu menggunakan alat musik maupun tanpa alat musik.

Dalam praktik penguasaan instrumen musik gesek yang terdiri dari : violin, viola,cello, contrabass dibutuhkan kekuatan musikal untuk mendukung keberhasilan dalam pembelajaran instrumen, hal tersebut menjadi sangat penting karena setiap unsur musikal akan berperan ataupun bersinergi dengan setiap teknik yang terdapat dalam instrumen gesek. Kekuatan musikal yang dibutuhkan untuk meningkatkan kualitas dalam penguasaan instrumen gesek, diantaranya adalah bagaimana seseorang dapat mendengar nada dengan baik serta penerapannya pada permainan instrumen gesek, sehingga dalam setiap nada akan tercipta sebuah tonalitas yang tepat dalam memainkan melodi maupun dalam menerapkan bentuk-bentuk ritmis secara tepat. 
Banyak kendala yang dihadapi seseorang manakala belajar berlatih musik khususnya instrumen gesek tanpa dukungan dari kekuatan musikal, misalnya seseorang yang tidak mempunyai kekuatan dalam mendengarkan nada dengan baik dalam mempelajari permainan instrumen biola, yang bersangkutan akan menghasilkan nada yang selalu kurang tepat atau fals yang tidak begitu enak didengar, hal tersebut tentunya akan selalu mengalami kesulitan dalam pendengarannya maupun dalam proses latihan yang terlalu lama. Demikian juga dalam hal pemahaman ritmis, seseorang yang tidak mempunyai kekuatan dalam penguasaaan ritmis yang baik, akan menjadi kendala dalam proses permainannya, misalnya ketepatan memainkan polapola ritmis yang agak sulit dalam sebuah komposisi concerto, maka sangat diperlukan penguasaan pola-pola ritmis yang terstruktur dengan baik agar bentuk permainan yang dihasilkan menjadi lebih baik dan sempurna. Hal tersebut sangat berhubungan dengan teknik gesekan yang ada di dalam permainan instrumen musik gesek (string instrument), karena kekuatan musikalitas itulah yang dapat mengakomodasi keberhasilan semua teknik dalam instrumen musik gesek

Untuk keberhasilan penerapan solfegio dalam penguasaan instrumen gesek, maka guru sangat berperan pada penggunaan metode pengajaran serta pengeloaan pengajaran sebagai upaya terhadap keberhasilan siswa pada penguasaan keterampilan bermain. Hal itu ada suatu prinsipprinsip pengajaran yang mendukung terlaksananya pengelolaan pengajaran dengan baik. Prinsip pengajaran meliputi: 1) Prinsip aktivitas, 2) Prinsip motivasi, 3) Prinsip individualitas, 4) Prinsip lingkungan, 5) Prinsip kebebasan, 6) Prinsip peragaan, 7) Prinsip kerjasama dan persaingan.

\section{B. PEMBAHASAN}

\section{Prinsip Aktivitas.}

Prinsip aktivitas merupakan hal yang berkaitan dengan aktivitas. Thomas M. Risk dalam bukunya Principles and Practices of Teaching (1958) mengemukaan bahwa pengalaman belajar itu sendiri hanya mungkin diperoleh jika peserta didik itu dengan keaktifannya sendiri bereaksi dengan lingkungannya (Rohani, 2004:6). Seorang guru dalam melaksanakan program pengajaran harus selalu memberikan kesempatan pada peserta didik agar selalu aktif dalam mengikuti proses pembelajaran yang sedang dilaksanakan. Dalam pelaksanaaan pembelajaran solfegio guru menyediakan bahan yang berupa materi ritmis, melodi, harmoni serta hal yang berkaitan dengan cara mendengarkan yang harus dipelajari peserta didik untuk mengolah, melatihnya, 
mendiskusikan serta bila mungkin membandingkan dengan hal-hal yang berhubungan dengan materi pelajaran.

Dalam pengajaran solfegio untuk penguasaan instrumen gesek, keaktifan peserta didik sangat menentukan keberhasilan program pengajaran. Praktik pembelajaran solfegio yang meliputi latihan ritmis, melodi harmoni merupakan suatu kegiatan yang sangat berpengaruh terhadap hasil yang dicapai oleh peserta didik, berlatih secara individu merupakan tuntutan mutlak bagi setiap peserta didik yang mengambil mata pelajaran instrumen gesek.

Jadi penerapan definisi tersebut pada pelaksanaan latihan praktik instrumen musik adalah pertama-tama bagaimana seorang peserta didik dalam menerapkan pengetahuan yang didapat dari guru mengenai cara-cara memainkan teknik bermain dalam instrumen musik gesek. Sebagai contoh sebelum berlatih instrumen violin peserta didik harus paham apa yang sebelumnya diinstruksikan guru praktik yang sesuai dengan materi yang diberikan. Aktivitas latihan yang teratur dengan cara latihan yang benar juga akan berpengaruh terhadap hasil yang akan dicapai. Aktivitas latihan peserta didik yang baik diluar maupun didalam proses pembelajaran, peranan guru dalam memberikan contoh-contoh yang benar merupakan suatu hal-hal yang penting.

Peranan guru terhadap murid-muridnya merupakan peran vital dari sekian banyak peran yang harus ia jalani. Hal ini dikeranakan komunitas utama yang menjadi wilayah tugas guru adalah didalam kelas untuk memberikan keteladanan, pengalaman serta ilmu pengetahuan kepada mereka. Begitupun peranan guru pada murid-muridnya tadi bisa dibagi menjadi dua jenis menurut situasi interaksi sosial yang mereka hadapi, yakni situasi formal dalam proses belajar mengajar di dalam kelas dan dalam situasi informal di luar kelas (Karsidi, 2007:81).

Di dalam situasi formal guru praktik instrumen musik sangat berperan dengan memberikan contoh-contoh yang positif misalnya cara meminkan instrumen musik gesek yang, cara membaca notasi dengan benar yang berupa penerapan unsur ritmis dan melodi dan sebagainya merupakan salah satu motivasi terhadap aktivitas peserta didik di luar pengajaran formal di dalam kelas.

Menurut Deborah V. Blair dalam artikelnya yang berjudul Mentoring novice teachers:developing a community of practice dalam Mentoring guru baru sangat penting untuk pendidikan musik, tidak hanya untuk tujuan retensi dan gesekan, tetapi juga untuk memberikan dukungan yang mereka butuhkan untuk menjadi praktisi profesional. Para peneliti secara konsisten melaporkan bahwa guru musik pemula berbagi perasaan kewalahan dengan tugas dan 
tanggung jawab mengajar. Disinilah perlu pemahaman proses pengajaran di dalam kelas dan pengembangan materinya secara professional serta komunitas dengan peserta didik juga ada sehingga guru bisa lebih mengetahui kegiatan peserta didik dalam mengikuti mata pelajaran yang diampu. Guru musik dan saya bertemu di salah satu ruang kelas musik dasar dan berbicara tentang topik yang sama - bagaimana mengatur ruang kelas musik dan bagaimana untuk memulai pengajaran musik. Pada penutupan pertemuan kami, saya menjelaskan sifat dari program mentoring, bahwa itu sukarela, akan fokus pada isu-isu untuk musik belajar dan mengajar, dan tidak akan menggantikan pertemuan lainnya induksi diperlukan. Saya juga berbagi bahwa saya berharap untuk menggunakan data yang dikumpulkan dari pertemuan kami dan korespondensi untuk studi lebih lanjut. Kami merencanakan untuk bertemu dua kali sebulan di ruang musik dari sebuah sekolah di pusat. Karena para guru mampu menggunakan pertemuan ini sebagai bagian dari yang diperlukan waktu mereka secara professional dalam mengelola pengajaran.

\section{Prinsip motivasi}

Motivasi berlatih bagi peserta didik yang belajar instrumen musik merupakan suatu hal yang sangat membantu keberhasilan dalam penguasaan permainan pada instrumen musik gesek yang sedang dipelajari. Terkadang seorang guru terlalu menekankan kepada peserta didik untuk selalu tekun berlatih, hal itu belum tentu menuai suatu keberhasilan, mengingat hal-hal yang selalu muncul dari inisiatif orang lain di luar dari individu itu sendiri akan menghambat proses aktivitas dari individu yang dalam hal ini adalah peserta didik.

Peran guru sebagai motivator justru akan membantu peserta didik dalam mengembangkan aktivitasnya sesuai dengan hal-hal yang ingin dicapai. Contoh misalnya seorang peserta didik pendidikan musik diberikan bahan/lagu ataupun etude (materi teknis) yang kurang menarik, maka peserta didik akan tidak termotivasi untuk melakukan latihan secara intensif. Di sini hendaknya guru bisa memilihkan bahan yang sesuai dengan tingkat keterampilan serta materi yang menarik untuk dipelajari peserta didik, dengan demikian peserta didik akan dengan senang melakukannya, sehingga terjadi perubahan bagi individu secara positif yaitu akan 
terjadi peningkatan keterampilan bagi peserta didik. Peran guru untuk memotivasi merupakan peran untuk keberhasilan pendidikan secara umum.

Individu sebenarnya tidak pernah ada dalam keadaan statis, artinya sebenarnya selalu terjadi perubahan didalam dirinya. Didalam proses pendidikan justru perubahan inilah yang menjadi pokok persoalan. Pendidikan berusaha merangsang dan memberi arah perubahan ini sesuai dengan cita-cita yang menjadi pedoman usaha itu (Suryabrata, 1998:8). Individu yang sebenarnya selalu berada dalam keadaan yang dinamis, sehingga motivasi yang diberikan oleh guru senantiasa dapat merangsang serta memberikan serta memberi arah sesuai dicita- perubahan yang positif yang citakan.

Dalam hal ini guru praktik instrumen musik gesek diharapkan selalu memberikan dorongan kepada peserta didik selain menganjurkan latihan yang teratur, juga memberikan kesempatan kepada peserta didik untuk banyak menimba ilmu di luar kegiatan formal yang ada di sekolah misalnya dengan mengikuti berbagai work shop mengenai instrumen musik yang dipilih, menonton konser-konser musik yang relevan dengan instrumen musiknya. Dengan mengikuti kegiatan tersebut maka peserta didik akan mempunyai motivasi belajar serta berlatih dengan baik, sehingga hasilnya sesuai dengan harapan pada diri peserta didik itu sendiri. Motivasi untuk belajar adalah motivasi insentif. Motivasi tersebut menggambarkan kecenderungan asli manusia untuk menggerakkan, mendominasi dan menguasai lingkungan sekelilingnya. Apabila motivasi tidak ada masih dapat ditimbulkan dengan cara membangkitkan harapan dalam diri seseorang. Harapan adalah antisipasi dari penghargaan yang akan diperoleh seseorang apabila orang tersebut memperoleh suatu tujuan yang diberikan. Suatu harapan dapat timbul dengan menceritakan sesuatu yang akan terjadi apabila ia telah menyelesaikan kegiatan belajarnya (Sujana, 1991:162).

Seorang individu akan terdorong melakukan sesuatu bila merasakan ada kebutuhan serta harapan yang dicita-citakan. Seorang peserta didik sekolah musik akan melakukan latihan secra individual apabila yang bersangkutan mempunyai motivasi untuk bermain musik secara baik dengan teknik yang benar.

\section{Prinsip Individualitas}

Setiap yang menyelenggarakan pengajaran hendaknya selalu memperhatikan dan memahami serta berupaya menyesuaikan bahan pelajaran dengan keadaan peserta didiknya, baik 
menyangkut perbedaan usia, bakat kemampuan, intelegensia, perbedaan fisik, watak dan sebagainya.

Prof. M. Athiyah Al-Abrosyi menegaskan bahwa sekiranya pelajaran yang diberikan kepada peserta didik yang sukar dipahami mereka, akibat akan hilang kepercayaan pada diri sendiri karena mereka tidak memperoleh santapan jiwa yang sesuai dengan pertumbuhan dan kemajuan akalnya (Rohani, 2004:6). Titik berat dalam permasalahan ini menekankan kepada halhal yang perlu diperhatikan bagi seorang guru yang dalam melaksanakan pengajaran agar selalu mempertimbangkan kemampuan setiap individu dalam pemberian materi pelajaran, karena pada dasarnya setiap individu mempunyai bakat dan kemampuan yang berbeda, mempunyai minat khusus yang berbeda,mepunyai latar belakang yang berbeda serta setiap individu mempunyai irama pertumbuhan dan perkembangan yang berbeda-beda.

Menurut Rohani (2004) dalam pemberian tugas yang perlu dipertimbangkan adalah:

1. Setiap memberikan tugas-tugas kelompok, hendaknya didasarkan pada tingkat kepandaian peserta didik.

2. Guru memberikan tugas-tugas unit dengan kemungkinan memilih macam-macam kegiatan dan pengalaman bagi setiap peserta didik.

3. Guru memberikan tugas-tugas individual kepada beberapa peserta didik setelah di dalam suatu kelompok.

4. Guru jangan memberikan tugas-tugas yang berupa hapalan-hapalan,tetapi perlu juga pengajaran dengan eksperimen, demonstrasi, pemecahan soal, dan tugas, dan penyelidikan yang mengandung motivasi dan membangkitkan aktivitas peserta didik. (2004:18)

Dalam proses pengajaran praktik instrumen musik gesek, pemberian materi awal hendaknya disesuaikan dengan kemampuan peserta didik dengan melihat pada tes keterampilan pada masa awal pelajaran dimulai, agar individu dalam pelaksanaannya tidak mengalami banyak kendala dalam masalah-masalah yang menyangkut segi-segi teknis, misalnya guru bisa mengelompokan peserta didik menurut bahan materi meliputi lagu dan etude (materi teknik) yang disesuaikan tingkat kemampuan peserta didik dalam kelompok. Penggunaan metode yang tepat dalam pengajaran individual sangat penting seperti pendapat Walberg mengenai individualized instruction berikut ini. 
Students individual differences. From this point of view, mastery learning is a relatively minor accommodation because although it allows for difference in learning time. It calls for using essentially the same methods Walberg describe arrange of accommodations that schools can make to and materials to move all students toward mastery of the same achievement goals. A more powerfull form of accommodation is to retain the same achievement goals but introduce variation not only in time to learn but in methods and materials used to accomplish this learning. A still more extreme form of accommodation is to allow students pursue different achievement goals, as well as a great deal of autonomy in deciding not only what to learn but how yo learn it (Good \& Brophy, 1987: 360).

Pendapat tersebut di atas menyatakan bahwa dalam pengajaran individual dapat dilaksanakan degan metode tepat yaitu walaupun setiap individu mempunyai perbedaanperbedaan tetapi esensi materi dan metode pembelajaran harus sama sehingga dapat mencapai hasil yang sama. Cara yang lebih kuat untuk mengakomodasi hal tersebut adalah mempertahankan tujuan pembelajaran, namun juga memperkenalkan variasi pada saat pembelajaran. Tetapi hal tersebut bisa menimbulkan masalah baru yaitu ada kesempatan peserta didik untuk mengejar hasil yang berbeda dari tujuan yang akan dicapai semula, sehingga peserta didik tersebut leluasa memutuskan untuk memilih apa yang akan dipelajari dan bagaimana mempelajari. Dalam pengajaran musik pemberian materi yang berbeda diperbolehkan asal metode pengajaran sama dan dalam tujuan yang sama.

\section{Prinsip Lingkungan}

Faktor lingkungan tidak dapat dipisahkan dengan pelaksanaan proses pengajaran, karena lingkungan akan mempengaruhi perkembangan kepribadian peserta didik. Dengan adanya lingkungan belajar yang baik di luar lingkungan sekolah maka peserta didik akan dengan mudah mengadaptasikan dengan lingkungan di dalam lingkungan sekolah, seperti halnya pernyataan di bawah ini:

Lingkungan dalam pengelolaan pengajaran mempunyai pengaruh yang kuat dalam perkembangan peserta didik. Henry E. Garet berpendapat bahwa hasil penyelidikan lebih 
menentukan dalam hal intelegensi, fisik, dan reaksi inderawi. Adapun faktor lingkungan lebih berpengaruh dalam pembentukan kebiasaan, kepribadian, sikap, nilai, dan sebagainya. (Rohani, 2004:18).

Dalam pembelajaran musik pada situasi tertentu yang ada pada suatu lingkungan, bisa memberikan motivasi peserta didik untuk berlatih materi musik. Sebagai contoh di dalam lingkungan rumah yang mempunyai atensi yang tinggi terhadap musik akan memacu setiap peserta didik untuk melatih materi yang diberikan guru di sekolah secara tekun di rumah, sebaliknya apabila lingkungan tidak mendukung dengan adanya kegiatan musik di rumah, ada kemungkinan peserta didik tidak termotivasi untuk melatik materi yang diberikan guru di sekolah.

Selain itu kegiatan-kegiatan yang mendukung keberhasilan peserta didik berupa keikusertaan peserta didik dalam forum-forum musik di luar lingkungan sekolah akan membant peserta didik lembaga pendidikan musik untuk meningkatkan tingkat keterampilan, hal ini peserta didik dapat melakukan sharing dengan anggota lingkungan di luar sekolah sehingga peserta didik dapat masukan yang banyak di samping dari pengajarannya di sekolah juga dari hal-hal yang didapat di lingkungan luar sekolah.

Tirtaharja (1998:163) berpendapat manusia mempunyai sejumlah kemampuan yang dapat dikembangkan melalui pengalaman. Pengalaman itu terjadi karena interaksi manusia dengan lingkungannya, baik lingkungan fisik maupun lingkungan sosial manusia secara efisien dan efektif itulah yang disebut pendidikan. Dan latar tempat berlangsungnya pendidikan itu disebut lingkungan pendidikan, khususnya pada tiga lingkungan utama pendidikan yakni keluarga, sekolah, dan masyarakat.

Di lingkungan keluarga, peserta didik mendapatkan kontrol dari orang tua dengan memberikan nasehat serta dorongan untuk selalu belajar materi-materi musik yang diberiakan oleh guru praktik di sekolah, hal ini harus ada hubungan yang sinergis antara oranag tua dan sekolah yang dalam hal ini guru praktik sebagai pengampu mata pelajaran praktik instrumen musik secara langsung. Sebagai contoh jika peserta didik telah mendapatkan materi pelajaran yang telah diberikan guru di sekolah tetapi tidak pernah mendapatkan respon yang baik dari peserta didik maka guru berhak menanyakan tingkat kesulitan apa yang dihadapi peserta didik kepada orang tua selaku penanggung jawab kegiatan peserta didik di lingkungan keluarga. 
Sedangkan di lingkungan masyarakat di samping peserta didik bisa belajar bersosialisasi dalam musik, peserta didik juga dapat melakukan perbandingan antara ilmu yang didapat dengan kebutuhan dalam masyarakat, karena terkadang apa yang dibutuhkan di masyarakat tidak sesuai dengan yang didapat di sekolah. Misalnya pada lembaga pendidikan musik diajarkan musik klasik pada kenyataannya belum tentu semua bisa diterapkan di lingkungan masyarakat pada umumnya, karena kehidupan di masyarakat sangat kompleks.

Faktor lingkungan adalah faktor yang besar pengaruhnya terhadap keberhasilan pelaksanaan pendidikan, terutama dalam lingkungan sosial yang merupakan tempat di mana individu-individu dapat berinteraksi antar sesama sehingga terjadilah proses sosial yang mempengaruhi perkembangan pribadi anak, dari lingkungan sosial ini terjadi proses pergaulan sesama individu. Menurut Lavengeld (Suwarno, 1985:35) pergaulan merupakan lapangan yang menjadi tempat berlangsungnya pekerjaan mendidik, tetapi tidak semua situasi pergaulan dapat member kemungkinan berlangsungnya pekerjaan mendidik, sebab pergaulan itu beraneka ragamnya, ada pergaulan yang mengandung hubungan antara orang dewasa dan anak, atau antara anak dan anak, dan mungkin antara orang dewasa dan orang dewasa.

Seperti halnya dalam penguasaan praktik instrumen bagi peserta didik, pola latihan individu hasilnya akan ditentukan oleh di mana peserta didik tersebut berada dalam lingkungan sosialnya dan dengan siapa dia bergaul di lingkungan luar sekolah. Kalau peserta didik berada pada lingkungan yang penuh atensinya terhadap musik yang sedang dipelajari, maka akan mendorong kemajuan peserta didik tersebut kearah yang positif misalnya dalam hal mengembangkan teknik yang di dapat dari lingkungan sekolah.

Apabila peserta didik berada dalam lingkungan yang mempunyai latar belakang musik di luar lingkungan sekolah dan musiknya sesuai dengan yang dipelajari di sekolah maka tentunya akan mendukung untuk kemajuan penguasaan tingkat keterampilannya, terutama yang menyangkut segi-segi teknis. Namun jika berada pada lingkungan orang yang lebih dewasa dan mempunyai kesamaan musik yang sedang dipelajari, maka peserta didik bisa belajar dari yang lebih dewasa untuk penguasaan keterampilannya. Maka dengan berdasarkan prinsip pengajaran ini diharapkan guru tidak terlalu untuk menekan peserta didik dan menghalangi untuk belajar di luar lingkungan sekolah sebagai bahan perbandingan. Karena dengan demikian justru akan menambah wawasan yang luas bagi peserta didik. 


\section{Prinsip Kebebasan}

Setiap individu mempunyai kemampuan yang tumbuh dari inisiatif diri sendiri, hal itu dapat mendasari dalam setiap pengajaran individual, di mana peserta didik diberikan kebebasan untuk melaksanakan pembelajaran dengan tetap dibimbing oleh guru, seperti halnya dengan pengertian kebebasan di bawah ini :

Kebebasan menurut Linskie (Rohani, 2004:19) mengandung tiga dimensi, yaitu:

a. Self directions, bagaimana individu bisa membimbing diri sendiri.

b. Self discipline, harus datang dari diri sendiri.

c. Self control, control diri juga harus datang dari diri sendiri.

Pengertian self directions bisa diterapkan dalam pengelolaan pengajaran praktik instrumen musik gesek yaitu guru memberikan keleluasaan kepada peserta didik untuk bisa membimbing diri sendiri di samping bimbingan dari guru itu sendiri. Peserta didik bisa membimbing diri sendiri pada saat peserta didik latihan instrumen musik secara individu dengan dilandasi hal-hal yang telah diajarakan oleh guru praktik instrumen. Dengan harapan peserta didik bisa mengembangkan teknik yang diajarkan guru atas inisiatif dari dirinya sendiri tanpa harus ada paksaan dari pihak di luar dirinya. Guru harus memberikan motivasi serta percaya diri kepada peserta didik untuk bisa mengatasi permasalahan praktik instrumen dalam kapasitasnya sebagai peserta didik.

Pengertian self discipline bisa diartikan bagaimana peserta didik mendisiplinkan diri dalam melatih bahan atau materi yang diberikan oleh guru, kesadaran untuk mempelajari pada setiap harinya sebaiknya datang dari diri sendiri termasuk bagaimana dia mengelola waktu latihan secara intensif. Tugas guru dalam hal ini memberikan gambaran kepada peserta didik bahwa latihan secara individu tersebut adalah sangat penting untuk kemajuannya sendiri. Guru bisa memberikan contoh-contoh konkrit tentang keberhasilan yang dapat dicapai apabila mendisiplinkan latihan secara teratur serta efektif, serta memberikan arahan tentang jumlah waktu yang disediakan untuk melakukan latihan setiap harinya. Disiplin merupakan bagian yang penting dalam interaksi belajar mengajar.

Di dalam interaksi belajar mengajar membutuhkan disiplin. Disiplin dalam interaksi belajar mengajar ini diartikan sebagai suatu pola tingkah laku yang diatur sedemikian rupa 
menurut ketentuan yang sudah ditaati oleh semua pihak dengan secara sadar, baik pihak guru maupun pihak peserta didik. Mekanisme konkrit dari ketaatan pada ketentuan atau tata tertib ini akan terlihat dari pelaksanaan prosedur yan sudah digariskan. Penyimpangan dari prosedur, berarti suatu indikator pelanggaran disiplin (Karsidi, 2007:68).

Dalam pengajaran praktik instrumen mayor, kesadaran peserta didik dalam mengelola disiplin dalam dirinya merupakan refleksi dari guru dalam menjalankan tugasnya secara disiplin, apabila peserta didik dianjurkan untuk tekun berlatih secara teratur, setidaknya guru memberikan contoh mengenai kedisiplinan latihan instrumen dengan teratur dan menurut ketentuan latihan yang sudah diterapkan.

Pengertian self control bagi peserta didik praktik instrumen mayor diartikan bagaimana peserta didik mengevaluasi diri serta mengontrol tentang apa yang selama ini sudah dilakukan dalam melaksanakan tugas yang diberikan oleh guru disekolah, dengan melihat hasil yang sudah dicapai dalam kurun waktu tertentu. Dengan adanya usaha untuk mengontrol diri sendiri, maka peserta didik akan tahu di mana letak kekurangannya dan kelemahannya sehingga akan lebih mudah untuk memperbaiki. Biasanya peserta didik akan melakukan kontrol diri apabila melihat perkembangan yang dicapai antar peserta didik, hasil yang lebih tinggi di antara mereka dalam istilah lain ada semacam persaingan untuk mendapatkan hasil terbaik.

Tugas guru dalam hal ini adalah bagaimana caranya menciptakan suasana kompetitif dalam belajar sehingga peserta didik berusaha untuk mendapatkan suatu tingkat keterampilan yang mereka inginkan dengan didasari kemampuan yang ada pada diri peserta didik itu sendiri.

Eddie MC Nacmara juga mengemukakan sebuah teori yaitu A Theoretical framework of self-regulation:

1. Self monitoring, The firs stage in the self regulation of behavior is self observation. This stage involves deliberately and carefully attending to one own behavior.

2. Self evalution, The second stage of the process consist of comparison being made between the information obtained from self monitoring and the self set criterion for the given behavior.

3. Self reinforcement, The third stage of self regulation of behavior consist of self reinforcement contingent upon the degree to which the actual behavior approximates 
to matches, or deviates from, the performance standar or criterion, ie From the intended behavioue (Namara, 1999:73).

Self monitoring diatas membahas mengenai hal-hal yang berhubungan dengan konsep intropeksi diri, melihat segala sesuatu yang ada pada dirinya, sehingga perlu dengan hati-hati dalam berperilaku. Konsep ini bila diterapkan dalam pola pembelajaran praktik instrumen musik, yaitu dalam memulai latihan peserta didik selalu melihat kekurangan dan kelemahannya pada penguasaan instrumen musiknya, dengan demikian kurang dikuasai, sehingga pelaksanaan latihan secara individual akan lebih effektif. Guru dalam hal ini juga harus memberikan kisi-kisi yang jelas mengenai cara-cara latihan yang efektif yang didasarkan pada Self monitoring itu sendiri.

Dalam Self Evaluation di atas berisi tentang membuat perbandingan, diantaranya tentang informasi yang diperoleh dari self monitoring dan self set criterion (standar diri) yang mesti diterapkan pada diri sendiri. Definisi tersebut bila diterapkan pada pembelajaran praktik instrumen mayor yaitu bahwa seorang peserta didik dalam melakukan latihan individu, untuk mencapai hasil yang diharapkan harus tahu sejauh mana ukuran keterampilan yang akan dia kuasai, hal itu untuk menakar banyaknya waktu latihan yang diperlukan serta untuk memfokuskan hal-hal yang bersifat teknis yang harus dia lakukan.

Dalam artikel yang ditulis oleh Chee Hoo Lum, Beyond music lesson:subject teachers' use of music in the classroom, Temuan ini menunjukkan bahwa guru musik pelatihan, pengaruh dan preferensi, bersama dengan pertimbangan kebutuhan kurikuler, dan pengelolaan kelas, semua faktor dalam menentukan jumlah dan jenis musik yang dibawa ke dalam kelas. Pendekatan aktif oleh guru untuk menanamkan minat musik anak-anak ke dalam praktek kelas mereka melayani untuk memvalidasi pengalaman musik anak-anak dan kompetensi di luar sekolah, mendorong sikap positif terhadap musik di kelas

Juga dalam setiap pertanyaan dari guru dalam hal music tradisional daerah seperti yang telah disampaikan Lum (2008:141) berikut.

The guiding research questions included:

1. What musical repertoire is being used in mother-tongue language classes by teachers? 
2. What are the functions of music in these mother-tongue language classes?

3. What are the lived experiences and responses of teachers and children towards music in these mother-tongue language classes?

4. What are the implications for practice of including music within mother tongue language classes?

Dengan memadukan antara musik daerah dalam proses pembelajaran praktik maka peserta didik akan lebih menyenangi musik tradisional serta akan melestarikan budaya daerah.

\section{Prinsip Peragaan}

Setiap individu mempunyai kemampuan yang tumbuh dari inisiatif diri sendiri, hal itu dapat mendasari dalam setiap pengajaran individual, di mana peserta didik diberikan kebebasan untuk melaksanakan pembelajaran dengan tetap dibimbing oleh guru, seperti halnya dengan pengertian kebebasan di bawah ini :

Pengertian kebebasan menurut Linskie (Rohani, 2004:19) mengandung tiga dimensi yaitu:

d. Self directions, bagaimana individu bisa membimbing diri sendiri.

e. Self discipline, harus datang dari diri sendiri.

f. Self control, control diri juga harus datang dari diri sendiri.

Pengertian self directions bisa diterapkan dalam pengelolaan pengajaran praktik instrumen musik gesek yaitu guru memberikan keleluasaan kepada peserta didik untuk bisa membimbing diri sendiri di samping bimbingan dari guru itu sendiri. Peserta didik bisa membimbing diri sendiri pada saat peserta didik latihan instrumen musik secara individu dengan dilandasi hal-hal yang telah diajarakan oleh guru praktik instrument musik gesek. Dengan harapan peserta didik bisa mengembangkan teknik yang diajarkan guru atas inisiatif dari dirinya sendiri tanpa harus ada paksaan dari pihak di luar dirinya. Guru harus memberikan motivasi serta percaya diri kepada peserta didik untuk bisa mengatasi permasalahan praktik instrumen dalam kapasitasnya sebagai peserta didik.

Pengertian self discipline bisa diartikan bagaimana peserta didik mendisiplinkan diri dalam melatih bahan atau materi yang diberikan oleh guru, kesadaran untuk mempelajari pada setiap harinya sebaiknya datang dari diri sendiri termasuk bagaimana dia mengelola waktu 
latihan secara intensif. Tugas guru dalam hal ini memberikan gambaran kepada peserta didik bahwa latihan secara individu tersebut adalah sangat penting untuk kemajuannya sendiri. Guru bisa memberikan contoh-contoh konkrit tentang keberhasilan yang dapat dicapai apabila mendisiplinkan latihan secara teratur serta efektif, serta memberikan arahan tentang jumlah waktu yang disediakan untuk melakukan latihan setiap harinya. Disiplin merupakan bagian yang penting dalam interaksi belajar mengajar.

Dalam pengajaran praktik instrumen mayor, kesadaran peserta didik dalam mengelola disiplin dalam dirinya merupakan refleksi dari guru dalam menjalankan tugasnya secara disiplin, apabila peserta didik dianjurkan untuk tekun berlatih secara teratur, setidaknya guru memberikan contoh mengenai kedisiplinan latihan instrumen dengan teratur dan menurut ketentuan latihan yang sudah diterapkan.

Pengertian self control bagi peserta didik praktik instrumen musik gesek, diartikan bagaimana peserta didik mengevaluasi diri serta mengontrol tentang apa yang selama ini sudah dilakukan dalam melaksanakan tugas yang diberikan oleh guru disekolah, dengan melihat hasil yang sudah dicapai dalam kurun waktu tertentu. Dengan adanya usaha untuk mengontrol diri sendiri, maka peserta didik akan tahu di mana letak kekurangannya dan kelemahannya sehingga akan lebih mudah untuk memperbaiki. Biasanya peserta didik akan melakukan kontrol diri apabila melihat perkembangan yang dicapai antar peserta didik, hasil yang lebih tinggi di antara mereka dalam istilah lain ada semacam persaingan untuk mendapatkan hasil terbaik.

Tugas guru dalam hal ini adalah bagaimana caranya menciptakan suasana kompetitif dalam belajar sehingga peserta didik berusaha untuk mendapatkan suatu tingkat keterampilan yang mereka inginkan dengan didasari kemampuan yang ada pada diri peserta didik itu sendiri.

Namara (1999:73) juga mengemukakan sebuah teori yaitu A Theoretical framework of self-regulation:

4. Self monitoring, The firs stage in the self regulation of behavior is self observation. This stage involves deliberately and carefully attending to one own behavior.

5. Self evalution, The second stage of the process consist of comparison being made between the information obtained from self monitoring and the self set criterion for the given behavior. 
6. Self reinforcement, The third stage of self regulation of behavior consist of self reinforcement contingent upon the degree to which the actual behavior approximates to matches, or deviates from, the performance standar or criterion, ie From the intended behavioue.

Self monitoring diatas membahas mengenai hal-hal yang berhubungan dengan konsep intropeksi diri, melihat segala sesuatu yang ada pada dirinya, sehingga perlu dengan hati-hati dalam berperilaku. Konsep ini bila diterapkan dalam pola pembelajaran praktik instrumen musik, yaitu dalam memulai latihan peserta didik selalu melihat kekurangan dan kelemahannya pada penguasaan instrumen musiknya, dengan demikian kurang dikuasai, sehingga pelaksanaan latihan secara individual akan lebih effektif. Guru dalam hal ini juga harus memberikan kisi-kisi yang jelas mengenai cara-cara latihan yang efektif yang didasarkan pada Self monitoring itu sendiri.

Dalam Self Evaluation di atas berisi tentang membuat perbandingan, diantaranya tentang informasi yang diperoleh dari self monitoring dan self set criterion (standar diri) yang mesti diterapkan pada diri sendiri. Definisi tersebut bila diterapkan pada pembelajaran praktik instrumen musik gesek yaitu bahwa seorang peserta didik dalam melakukan latihan individu, untuk mencapai hasil yang diharapkan harus tahu sejauh mana ukuran keterampilan yang akan dia kuasai, hal itu untuk menakar banyaknya waktu latihan yang diperlukan serta untuk memfokuskan hal-hal yang bersifat teknis yang harus dia lakukan.

Dalam artikel yang ditulis oleh Chee Hoo Lum, Beyond music lesson:subject teachers' use of music in the classroom, Temuan ini menunjukkan bahwa guru musik pelatihan, pengaruh dan preferensi, bersama dengan pertimbangan kebutuhan kurikuler, dan pengelolaan kelas, semua faktor dalam menentukan jumlah dan jenis musik yang dibawa ke dalam kelas. Pendekatan aktif oleh guru untuk menanamkan minat musik anak-anak ke dalam praktek kelas mereka melayani untuk memvalidasi pengalaman musik anak-anak dan kompetensi di luar sekolah, mendorong sikap positif terhadap musik di kelas

Juga dalam setiap pertanyaan dari guru dalam hal music tradisional daerah seperti yang telah disampaikan Lum (2008:141) berikut:

The guiding research questions included: 
5. What musical repertoire is being used in mother-tongue language classes by teachers?

6. What are the functions of music in these mother-tongue language classes?

7. What are the lived experiences and responses of teachers and children towards music in these mother-tongue language classes?

8. What are the implications for practice of including music within mother tongue language classes

Dengan memadukan antara musik daerah dalam proses pembelajaran praktik maka peserta didik akan lebih menyenangi musik tradisional serta akan melestarikan budaya daerah.

Di dalam pengelolaan pengajaran praktik instrumen musik gesek, prinsip peragaan dalam setiap pelaksanaan pengajaran adalah sangat penting untuk dilakukan oleh guru sebagai pengampu mata pelajaran praktik instrumen. Hal ini didasarkan pada esensi dari praktik memainkan instrumen musik itu sendiri memerlukan suatu bentuk contoh permainan yang dilakukan guru untuk nantinya ditiru oleh peserta didik. Ghazali (Rohani,2004:23) mengatakan agar peserta didik mudah mengingat, menceritakan dan melaksanakan pelajaran yang pernah diamati di kelas, hal demikian perlu didukung dengan peragaan-peragaan sebagai media pengajaran yang konkrit.

Dengan memberikan dasar-dasar teknik permainan, guru harus memberikan contoh permainan yang konkrit, agar peserta didik bisa memahami dengan jelas cara memainkan instrumen dengan baik dan benar, kalau hanya berbentuk instruksi-instuksi lisan tanpa contoh, maka peserta didik dimungkinkan akan terjadi kesalahan persepsi dalam menerima pelajaran, sehingga akan mengakitbatkan kesalahan teknik dalam bermain. Perlu diketahui bahwa apabila peserta didik sudah terlanjur memainkan instrumen musik dengan teknik yang salah, maka akan sulit dilakukan untuk mengembalikan pada teknik permainan yang benar. Peragaan atau demontrasi adalah wajib dilakukan oleh seorang guru praktik instrumen, seperti halnya dalam definisi di bawah ini:

Demonstration provide teachers with an opportunity to show student a procedure or illustration from which they will be able to learn. Teachers more commonly use demonstration to model particular skills that students are expected to learn (Kinsvatter, 1996:253). 
Demontrasi atau peragaan memberikan kesempatan bagi guru untuk menunjukkan prosedurprosedur ataupun ilustrasi-ilustrasi yang jelas kepada peserta didik sehingga akan memberikan keinginan belajar peserta didik yang lebih tinggi.

\section{Prinsip Kerja sama dan Persaingan}

Dalam setiap kegiatan pembelajaran di sekolah, kerja sama dan persaingan antar peserta didik merupakan hal yang apabila dilakukan dengan suatu tujuan yang positif akan meningkatkan kualitas hasil pembelajaran. Jean D. Grambs (Rohani, 2004:24) berpendapat bahwa dalam pengajaran di sekolah yang demokrasi, baik kerja sama maupun persaingan sama pentingnya. Hanya saja persaingan tidak berarti persaingan antar kelompok. Dan persaingan yang dimaksud bukan bermaksud untuk memperoleh hadiah kenaikan tingkat, tetapi untuk mencapai hasil yang lebih tinggi atau pemecahan masalah.

Persaingan dalam belajar merupakan suatu kegiatan yang positif, karena akan meningkatkan hasil yang lebih baik. Demikian halnya dalam pelaksanaan pembelajaran praktik instrumen musik gesek, adanya suatu persaingan dan berlomba untuk menghasilkan yang terbaik sangatlah diperlukan. Guru sebaiknya dapat menciptakan suasana yang mencerminkan adanya suatu persaingan dalam penguasaan instrumen musik secara baik, namun disamping itu juga harus ada suatu kerja sama dalam belajar sehingga akan sangat membantu peserta didik dalam mengatasi segala permasalahan yang bersifat teknis dalam bermain musik sesama teman berlatihnya.

Prinsip-prinsip pengajaran tersebut menjadi dasar bagi terlaksananya pengelolaan pengajaran dalam lingkup pembelajaran praktik instrumen, dengan meningkatkan keterampilan motorik dalam bidang musik.

Istilah keterampilan motorik (perceptual motor skill) adalah serangkaian gerakan otot (muscular) untuk menyelesaikan tugas dengan berhasil. Gerakan-gerakan otot yang terkoordinasi, dikoordinasi oleh persepsi kita terhadap peristiwa-peristiwa luar dalam lingkungan sekitar kita. Pengertian persepsi menunjuk pada cara individu mengorganisasi dan menafsirkan informasi yang datang kepada seseorang melalui macam-macam alat penginderaan. Motor menunjuk pada gerakan-gerakan otot (Hamalik, 2003:173).

Dalam pengajaran praktik instrumen yang paling penting adalah bagaimana meningkatkan keterampilan motorik peserta didik untuk menghasilkan kualitas permainan yang lebih baik 
dengan melalui pola pengajaran yang mengacu pada model pembelajaran musik secara individual, karena dengan memperhatikan perkembangan keterampilan motorik peserta didik secara individual, maka guru akan mengetahui sejauh mana pencapaian materi pengajaran yang diberikan.

\section{KESIMPULAN.}

Dalam pelaksanaan pembelajaran praktik instrumen musik gesek bisa dengan menerapkan prinsip-prinsip pengajaran yang meliputi prinsip aktivitas, prinsip motivasi, prinsip individualitas, prinsip lingkungan, prinsip kebebasan, prinsip peragaan, prinsip kerjasama dan persaingan. Diharapkan dengan menggunakan prinsip tersebut para peserta didik ada peningkatan dalam kualitas permainan pada instrumen musik gesek.

\section{DAFTAR PUSTAKA}

Rohani, Ahmad. 2004. Pengelolaan Pengajaran, Jakarta: Penerbit Rineka Cipta

Lum, Chee-Hoo. 2008. Beyond music lesson:subject teachers use of music in the class room, Research Studies in Music Education, National Institute of Educational/Namyang Technological University, Singapore.

Namara, Eddie MC. 1999. Positive Pupil Management and Motivation, Secondary teachers guide, David Fulton Publishers. USA.

Hamalik, Oemar. 2002. Pendidikan guru:Berdasarkan Pendekatan Kompetensi, Jakarta: Gramedia.

Kindsvatter, Richard. 1996. Dynamics of effective teaching. USA: Longman Publisher,.

Sudjana, Nana. 1991. Teori-teori belajar untuk pengajaran. Jakarta: Lembaga Penerbit Fakultas Ekonomi Universitas Indonesia.

Suryabrata, Sumadi. 1998. Psikologi Penelitian, Jakarta: PT. Raja Grafindo Persada. 